\title{
PEGEMBANGAN UMKM JAJAN SENGAIT DI DESA SADING MELALUI INOVASI BRANDING DAN PACKAGING
}

\section{DEVELOPMENT OF SENGAIT SNACK MSMES IN SADING VILLAGE THROUGH BRANDING AND PACKAGING INNOVATION}

\author{
Ida Ayu Laksmi Nirmala Sari ${ }^{1)}$, Dewa Ayu Putu Adhiya Garini Putri ${ }^{2)}$ \\ ${ }^{1,2}$ Program Studi Teknik dan Informatika, Universitas Pendidikan Nasional \\ ${ }^{1}$ Email: laksminirmala1@gmail.com
}

\begin{abstract}
Abstrak: Kekacauan di sektor ekonomi akibat pandemi Covid-19 menyebabkan UMKM yang bergerak di sektor produksi makanan Jajan Sengait di Desa Sading, Kecamatan Mengwi, Kabupaten Badung mengalami kesulitan mendapatkan penghasilan karena diberlakukannya PPKM yang membuat mereka kesulitan dalam memasarkan produk mereka. Pemasaran yang terbatas dan sederhananya kemasan produk membuat produk kurang menarik dan kurang dikenal masyarakat. Untuk mengatasi permasalahan tersebut pelaksana merencanakan program yang berkaitan dengan inovasi branding dan packaging dari produk jajan sengait, dimana hal ini bertujuan untuk memperluas pasar. Program ini dimulai dengan membuat logo dan memilih kemasan yang sesuai untuk produk, setelah itu dilanjutkan dengan pembuatkan akun media sosial Instagram. Hasil setelah dilakukannya program kerja ini, usaha jajan sengait kini memiliki kemasan yang lebih menarik dan dengan dibuatnya akun Instagram sengait.sading membuat usaha ini lebih dikenal dikenal oleh masyarakat.
\end{abstract}

Kata Kunci: Desa Sading, Ekonomi, Sengait

\begin{abstract}
The chaos in the economic sector due to the Covid-19 pandemic has caused MSMEs engaged in the food production sector to Snack Sengait in Sading Village, Mengwi District, Badung Regency to have difficulty getting income due to the implementation of PPKM which makes it difficult for them to market their products. Limited marketing and simple product packaging make the product less attractive and less well known to the public. To overcome these problems, the executor plans a program related to branding and packaging innovations of sengait snack products, which aims to expand the market. This program begins with creating a logo and choosing the appropriate packaging for the product, after that it is continued with the creation of an Instagram social media account. The result after this work program was carried out, the sengait snack business now has a more attractive packaging and the creation of an Instagram account makes this business better known to the public.
\end{abstract}

Keywords: Sading village, Economic, Sengait 
INTEGRITAS : Jurnal Pengabdian

Vol 5 No 2 Desember 2021

ISSN 2580 - 7978 (cetak) ISSN 2615 - 0794 (online)

\section{PENDAHULUAN}

Mahasiswa sebagai generasi penerus bangsa dituntut untuk mampu meningkatkan intelektualitas dan keterampilan (skill) demi terciptanya Sumber Daya Manusia (SDM) yang lebih berkualitas dan tanggap terhadap masalahmasalah yang timbul di tengah-tengah kehidupan masyarakat serta mampu mencari solusinya. Dalam merealisasikan dan mencapai tujuan tersebut di atas, maka dibentuklah suatu program Kuliah Kerja Nyata $(\mathrm{KKN})$ dimana mahasiswa akan terjun langsung ke lingkungan masyarakat sebagai implementasi terhadap ilmu pengetahuan yang diterima dibangku kuliah agar mahasiswa dapat menjawab tantangan zaman yang semakin pesat. Kuliah Kerja Nyata juga merupakan salah satu kegiatan dimana mahasiswa benar-benar menjunjung tinggi dan mengabdikan Tri Dharma Perguruan Tinggi.

Desa Sading merupakan salah satu desa di Bali yang terkenal akan kelezatan dan keunikan kulinernya terutama jajan-jajan tradisional Bali seperti jajanan kering sengait dan kue potongan. Pembuatan jajan tradisional tersebut dikerjakan di rumah-rumah penduduk sebagai home industri. Strategi pemasaran jajanan ini hanya dengan memajang produk mereka di warung dan menunggu pembeli datang, hal ini menjadi kendala dalam proses penjualan produk yang masih sederhana. Kendala kedua adalah kemasan dari produk dikemas dengan plastik yang sederhana, diikat dengan tali rafia atau direkatkan dengan api. Hal ini dirasa kurang ramah lingkungan dan ini mungkin menjadi salah satu hal yang membuat jajanan bali kurang dikenal masyarakat luas khususnya kalangan muda karena kurangnya inovasi pada pengemasan.

Ditambah lagi pada awal tahun 2020 berbagai negara di dunia mengalami musibah akibat adanya penyebaran Covid-19. Indonesia sebagai salah satu negara yang juga terkena dampak penyebaran virus Covid-19 segera melakukan berbagai tindakan antisipasi dengan cara pemberlakuan pembatasan kegiatan masyarakat (PPKM) dan menyarankan untuk melakukan social distance. Pandemi Covid-19 ini bukan hanya menyebabkan bencana kesehatan, namun juga telah menimbulkan kekacauan di sektor ekonomi. Contohnya UMKM yang bergerak di sektor produksi makanan Jajan Bali Sengait di Desa Sading Kecamatan Mengwi 
INTEGRITAS : Jurnal Pengabdian

Vol 5 No 2 Desember 2021

ISSN 2580 - 7978 (cetak) ISSN 2615 - 0794 (online)

Kabupaten Badung ini mereka mengalami kesulitan mendapatkan penghasilan karena diadakannya PPKM. Karena adanya pembatasan kegiatan antar wilayah ini membuat mereka kesulitan dalam menjual produknya. Minimnya pengetahuan khususnya dalam bidang dunia digital membuat mereka lebih mengandalkan pelanggan tetap yang terbatas dan tidak pasti. Padahal situasi pandemi Covid-19 ini memberikan tantangan untuk menjaga eksistensi UMKM apalagi jika dikaitkan dengan era teknologi digital untuk mendukung aktivitas ekonomi.

Dengan adanya masalah tersebut saya melalui program kegiatan Kuliah Kerja Nyata (KKN) merencanakan program kegiatan yang bertujuan untuk memperluas pasar dengan cara membuatkan media sosial Instagram serta membantu mendesain kemasan produk agar lebih menarik. Dengan kedua program tersebut diharapkan dapat membantu UMKM untuk memperluas pemasarannya sehingga bisa meningkatkan penjualan di masa pandemi Covid-19.

\section{METODE}

Metode awal yang dilakukan dalam kegiatan pengabdian masyarakat ini meliputi metode observasi dimana pelaksana mengadakan suatu pengamatan secara langsung pada rumah produksi Jajan Sengait. Dilanjutkan dengan metode wawancara melalui diskusi dan tanya jawab singkat dengan pelaku usaha mengenai semua hal yang berhubungan dengan pengemasan dan bagaimana sistem pemasaran produk jajan bali sengait. Kemudian ada metode dokumentasi merupakan pelengkap dari penggunaan metode observasi dan wawancara. Metode dokumentasi dilakukan dengan pengamatan secara langsung untuk melihat bagaimana kondisi kemasan produk dan gambaran pemasaran yang biasa dilakukan oleh pelaku usaha.
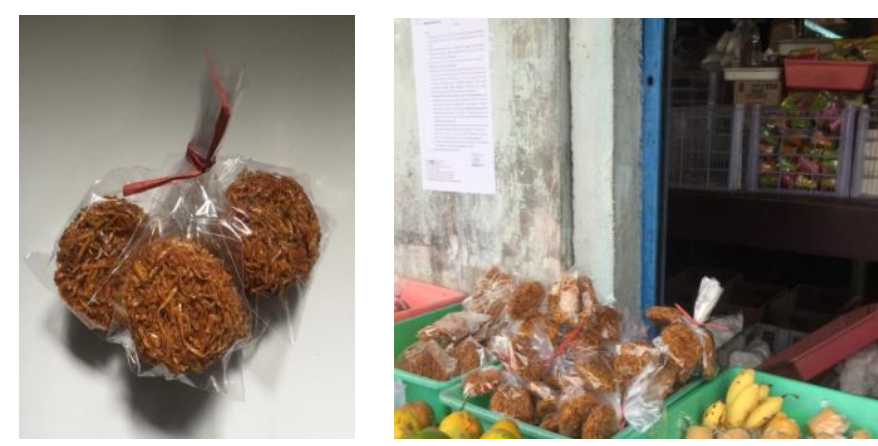

Gambar 1. Kemasan Produk Jajan Sengait 
Selanjutnya data-data tersebut akan diolah dengan dua tahapan pelaksanaan meliputi:

\section{A. Mendesain Logo dan Kemasan}

Pada tahap ini pelaksana membantu dalam mendesain logo dan kemasan. Apabila pemasaran diperluas, tidak menutup kemungkinan produk akan dijual lintas daerah. Proses logistik tersebut membutuhkan ketahanan produk yang lebih lama. Produk dijual per biji dengan harga Rp 1.000,00 dan tidak dibungkus tahan udara, hanya diikat menjadi satu kesatuan dengan tali raffia tanpa label dimana satu ikat berisi 5 biji jajan sengait. Karena kemasan yang masih sangat sederhana ini maka diperlukan pembuatan logo dan kemasan yang baru sehingga masyarakat lebih mengenal dan tertarik dengan produk yang akan dibeli. Hal ini didukung dengan penelitian dari Bo Rundh dalam literatur yang berjudul How Packaging Is Influencing the Marketing Strategy, dimana dikatakan bahwa kemasan dapat menarik perhatian para pembeli atau konsumen terhadap merek tertentu, meningkatkan citra, dan merangsang persepsi konsumen tentang produk. Berikut merupakan logo dan kemasan terbaru dari produk:
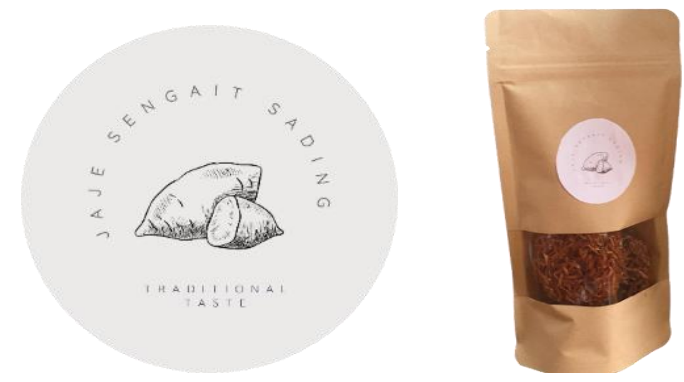

Gambar 2. Tampilan Logo dan Kemasan Terbaru

Pengemasan produk Jajan Bali Sengait ini diperbaharui kemasan produknya dengan menggunakan kemasan kertas. Pada dasarnya memang tidak wajib untuk merubah suatu kemasan. Namun untuk mengejar dan menyeimbangi wajah pasar pada saat ini, hal tersebut menjadi sebuah keharusan.

B. Membuat Akun Sosial Media Instagram

Salah satu upaya untuk memperluas pasar di masa pandemi Covid-19 bisa dilakukan dengan digitalisasi. Pelaku UMKM dikenalkan dengan media sosial instagram sebagai media untuk memperluas jangkauan pasar dan 
meningkatkan brand awareness, karena sebelumnya produk jajan sengait ini hanya dipasarkkan di warung-warung terdekat di sekitaran desa Sading. Pada tahapan ini pelaksana membantu pembuatan akun instagram, lalu pelaksana juga membantu dalam pembuatan desain gambar untuk tampilan instagram. Media social instagram dipilih karena digemari oleh berbagai kalangan usia. Untuk memperoleh perhatian dari berbagai kalangan tersebut, maka dibutuhkan konten yang menarik. Berikut merupakan akun instagram yang telah dibuat:

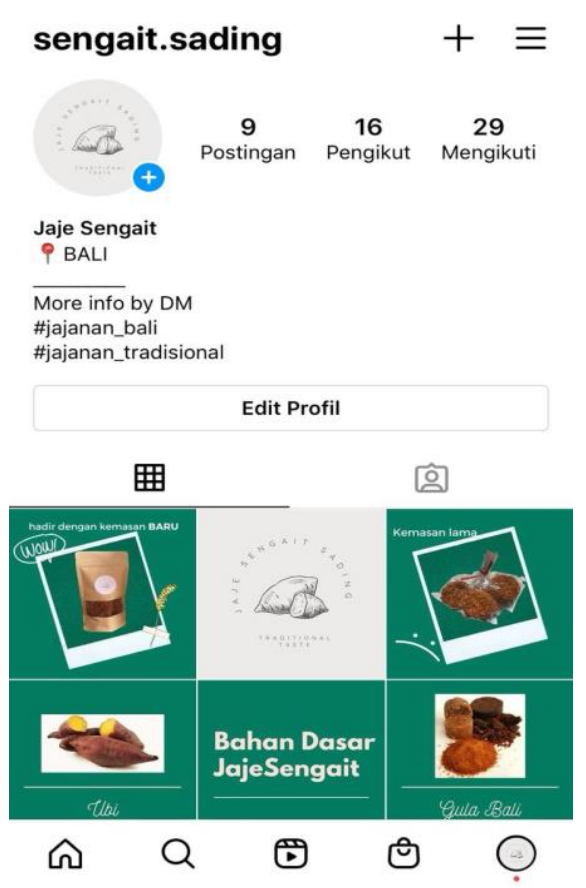

Gambar 3. Tampilan Akun Instagram Yang Telah Dibuat

\section{HASIL DAN PEMBAHASAN}

Setelah dilakukan kegiatan ini pelaku UMKM sudah mulai memahami pentingnya kemasan yang baik apabila dipasarkan pada pasar yang lebih luas. Pelaku UMKM yang sebelumya tidak memiliki logo pada kemasan produknya kini telah memiliki logo kemasan dengan desain yang lebih menarik. Sebelumnya desain logo telah dikoordinasikan dengan pelaku usaha sehingga menghasilkan logo yang simple dan menarik. Logo dan kemasan baru ini pun mendapat respons yang positif dari pengguna instagram. Berikut komentar yang diperoleh dari pengguna akun social media instagram: 


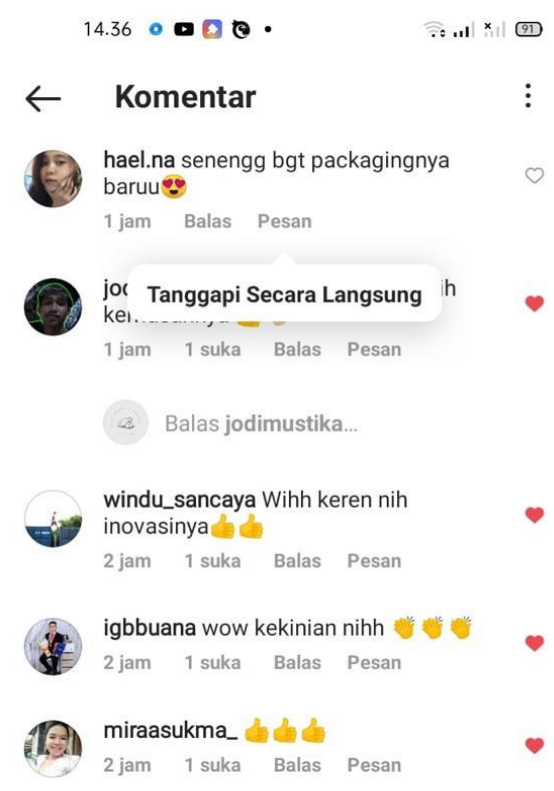

Gambar 4. Respons Dari Pengguna Instagram

Selain itu, dibuatnya akun instagram sebagai inovasi branding bagi UMKM jajan sengait ini membuahkan hasil berupa meluasnya jangkauan jaringan di masa pandemi Covid-19. Dan dalam kurun waktu 5 hari sejak dibuat akun ini sudah menjangkau lebih dari 40 akun baik pengikut maupun bukan pengikut. Berikut merupakan insight dari akun instagram yang telah dibuat:

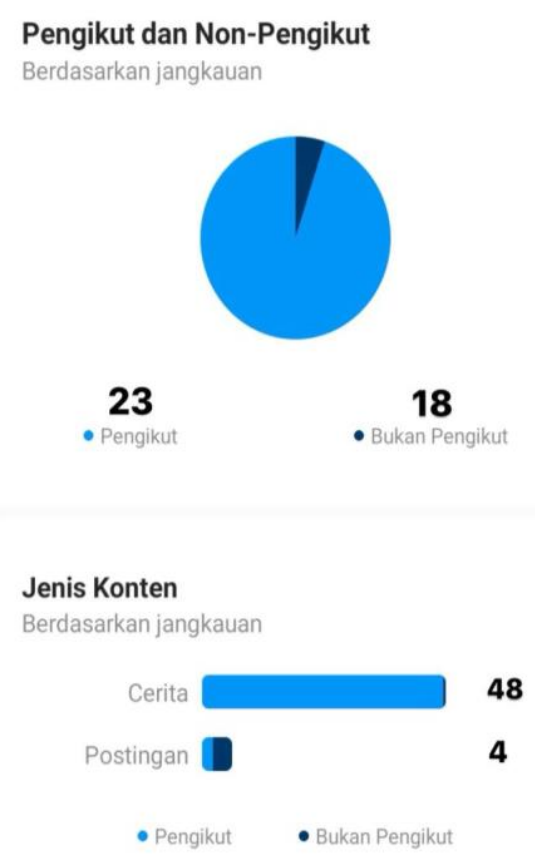

Gambar 5. Insight akun sengait.sading 
Terdapat beberapa perubahan pada sistem usaha produk UMKM Jajan Bali Sengait, hal-hal tersebut ditunjukkan pada table dibawah:

Tabel 1. Perbedaan Sebelum dan Sesudah KKN

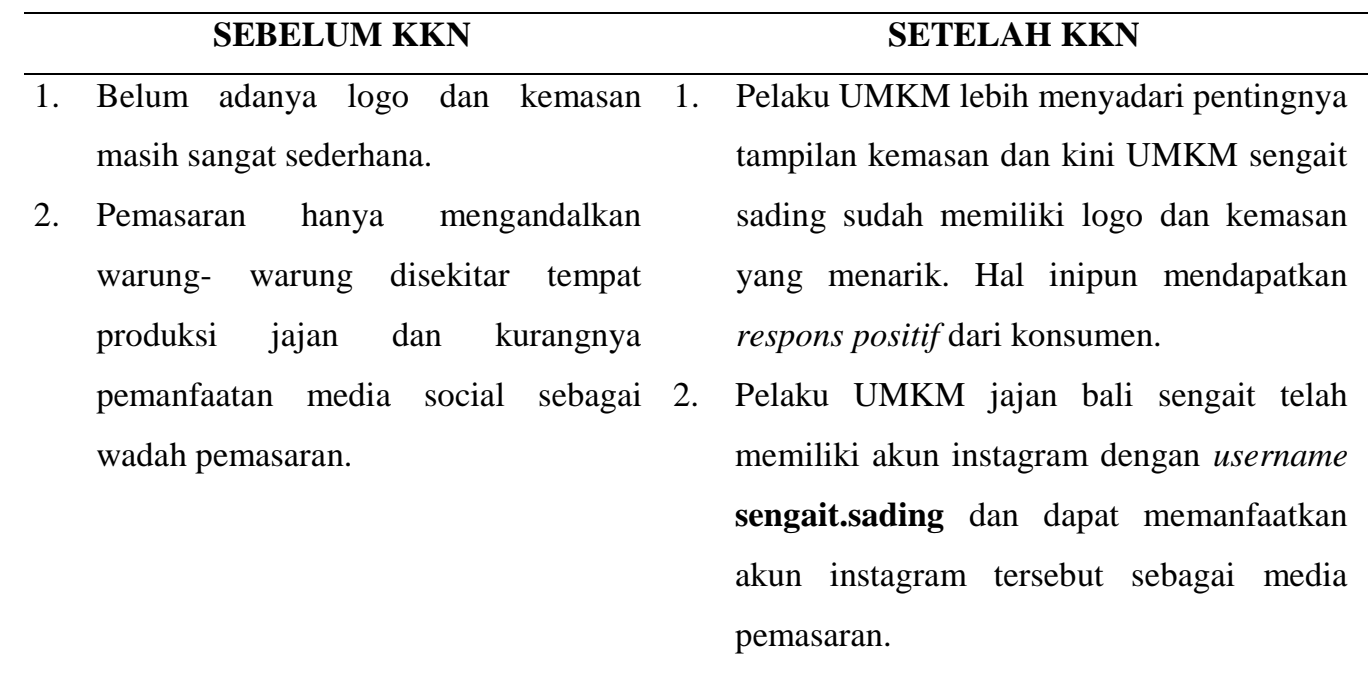

\section{KESIMPULAN}

Berdasarkan pembahasan diatas maka dapat disimpulkan bahwa dengan adanya inovasi branding dan packaging pada produk UMKM jajan sengait ini mampu membantu pelaku usaha untuk lebih memahami bahwa pertarungan suatu produk tidak lagi terbatas pada keunggulan kualitas saja, tetapi juga harus ada usaha untuk mendapatkan nilai tambah berupa emotional benefit kepada para konsumen, salah satu usaha yang dapat ditempuh untuk menghadapinya adalah melalui desain produk yang menarik. Selain itu memperluas pasar dengan branding melalui media sosial terbukti ampuh dilakukan dimasa pandemi Covid19 ini. Diharapkan strategi pengemasan yang menarik dan penggunaan media sosial instagram dapat terus dilakukan secara berkelanjutan dan dikembangkan kembali sehingga mampu membantu UMKM untuk memperluas pangsa pasar.

\section{UCAPAN TERIMA KASIH}

Pelaksana KKN mengucapkan terimakasih atas berbagai pihak yang terlibat dan mendukung agar kegiatan ini dapat terlaksana dengan baik. Secara khusus pelaksana mengucapkan terimakasih kepada LP2M Universitas Pendidikan Nasional, juga ucapan terimakasih kepada Ir. Dewa Ayu Putu Adhiya Garini Putri, ST., MT., IPM selaku Dosen Pembimbing yang telah membantu serta 
mengarahkan dalam penyusunan Laporan dan artikel kegiatan KKN. Tidak lupa kepada segenap pengurus INTEGRITAS Jurnal Pengabdian Masyarakat atas kesempatan yang diberikan.

\section{DAFTAR PUSTAKA}

Albarran, Allan B. 1996. Media Economics: Understanding Markets, industries, and Concepts. Iowa State University

Anggia, M. N., \& Shihab, M. R. (2018). Strategi Media Sosial Untuk Pengembangan Umkm. Jurnal Terapan Teknologi Informasi, 2(2), 159170.

Dwijayani,N.M., Pradnyawati, K.D., Yasa, I.W.S.A. Program Kemitraan Masyarakat Usaha Jajanan Tradisional Sengait Tabanan, 1(1), 47-53

Kartika, L.G.S., Korry, P.D.P, Putra, I.G.E.W. (2018). Peningkatan Usaha Jajanan Khas Desa Sading Melalui Transfer Teknologi Yang Efektif, 9(1)

Nasution, L.S.W., Nusa. P., Putra. D.S. (2021). Membangkitkan UMKM di Tengah Pandemi Covid-19, 1(1), 9-18

Nata, G.M.N., Suryawan, I.K.D, Yudiastra, P.P. (2018). Peningkatan Produktifitas Industri Rumah Tangga Jajan Tradisional Khas Gianyar. $9(1)$

Purnomo, F. (2019). Program Ladit (Lapak Digital): Optimalisasi Media Digital sebagai Wadah dalam Pengembangan Umkm di Madura. Jurnal Studi Manajemen Dan Bisnis, 6(2), 89-95

Putra, I. N. T. A., Kartini, K. S., \& Dewi, L. G. K. (2019). Sentuhan Digital Bisnis (Teknologi Informasi) pada UMKM Studi Kasus: Pemasaran Produk Adi Upakara. International Journal of Natural Science and Engineering. $3(2), 79-84$.

Setiawati, S.D., Retnasari, M., Fitriawati. D. (2019) Strategi Membangun Branding Bagi Pelaku Usaha Mikro Kecil Menengah. 2(1), 125-136

Sunarti, Puspita, H.N., Ernawati, R. (2018). Pengembangan Pemasaran Usaha Kue Tradisional Rumahan Melalui Media E-Commerce. 2(2) 